\title{
Old school ties: financial aid coordination and the governance of higher education ${ }^{1}$
}

\author{
Scott E. Masten \\ University of Michigan, School of Business Administration, Ann Arbor MI 48109-1234, USA
}

Received 26 July 1993; revised 8 March 1994

\begin{abstract}
This paper analyzes the role of financial aid coordination among the group of top northeastern colleges and universities known as the Overlap Group. Members of the Overlap Group met annually to tailor financial aid packages so that the out-of-the pocket contribution of parents to their children's education was the same regardless of the school the students chose to attend. I argue that the practices and stability of the Overlap Group are difficult to reconcile with traditional cartel theory and that financial aid coordination was a solution to organizational problems encountered in the education industry, particularly, to matching and externality problems arising in the allocation of elite students among educational institutions.
\end{abstract}

JEL classification: $\mathrm{I} 2 ; \mathrm{L} 4 ; \mathrm{L} 3$

Keywords: Nonprofits; Antitrust; Higher education; Collusion

\footnotetext{
${ }^{1}$ This research has benefitted from conversations with Debra Barbezat, Henry Hansmann, James Meehan, and Joel Slemrod and from the comments of Ian Ayres, Colin Campbell, Randy Kroszner, Ted Snyder, and participants at seminars at the University of Chicago, Dartmouth College, University of Illinois at Urbana-Champaign, University of Michigan, University of Pittsburgh, and the U.S. Federal Trade Commission and at an informal workshop at the Yale School of Organization and Management. Parts of this research were completed while I was John M. Olin Faculty Research Fellow at Yale Law School. Funding from the Center for Studies in Law, Economics, and Public Policy and from the University of Michigan School of Business Administration is gratefully acknowledged. Gautam Ahuja provided valuable research assistance.
} 
On May 22, 1991, after a two-year investigation, the Justice Department charged the eight Ivy League universities and the Massachusetts Institute of Technology with illegally fixing financial aid awards. The case against the schools, members of a broader association of colleges and universities known as the Overlap Group, rested on the analogy between the market for educational services and the standard product market of economic theory. According to the government's trial brief, "a university... is an enterprise offering educational services as its primary output" (1992, p. 49), "tuition represents the list price of attendance[, f]inancial aid awards are discounts from this stated price" (p. 11); and "the ban on merit scholarships served as a complete ban on competitive bidding" (p. 13). Initial published reactions of economists drew similar parallels. Lawyereconomist Ian Ayres likened educational institutions to cement manufacturers and argued "[a]n agreement to set the amount of financial aid is economically no different from a horizontal agreement among manufacturers to fix uniform discounts for their products" [Ayres (1989), p. 19]. In a similar vein, Gary Becker, equating students with car buyers, concluded that "No one has advanced persuasive reasons why anti-competitive practices by universities and other nonprofit organizations should be excluded, and there are good reasons why they should be subject to the antitrust laws"' [Becker (1989), p. 30].

The analogy underlying these assessments is, on its face, appealing. A college education is a major consumer purchase and, at a fundamental level, is subject to the same market forces that regulate the supply and demand for other commodities. On closer inspection, however, the nature of the education market proves hard to reconcile with the standard cartel model that forms the logical basis for antitrust proscriptions of collusion. Even if the theory of cartel behavior and stability extended to educational services, a number of market conditions would have to be satisfied for collusion to succeed. But educational transactions differ markedly from the standard product of economic theory. A satisfactory explanation of aid coordination should be consonant with the distinctive cconomic and institutional features of the education market.

The purpose of this paper is two-fold. The more specific aim is to analyze the purpose and effects of financial aid agreements as a basis for assessing the economic merits of the Overlap Group's practices. Toward that end, I consider first the potential for and implications of collusion among educational institutions within the framework of conventional cartel theory. I then question the validity of the analogy to standard product markets and discuss attributes of educational transactions that suggest nonstrategic motives for aid coordination. That analysis also illustrates the second, broader claim of the paper, namely, that conventional economic theories of market behavior may provide an inadequate basis for public policy prescriptions where nonstandard transactions or peculiar institutional or organizational arrangements are involved and that, in such cases, public policy would be better served by a conception of the problem of economic organization 
that explicitly recognizes the role and implications of nonstandard organizational forms.

In the next section of the paper, I provide a brief history of financial aid coordination and overview of the case. Sections 2 and 3 evaluate aid coordination, first, as a form of collusion and, then, as part of the solution to organizational problems confronted in the market for higher education. In section 4, I discuss ways in which the anticompetitive and efficiency interpretations of aid coordination might be distinguished empirically and present some evidence on the existence of pecuniary motives for aid collusion. Section 5 contains conclusions and policy recommendations.

\section{Background}

Financial aid coordination had its origins in the 1950's with a campaign by college administrators to encourage colleges to base financial aid awards on the demonstrated financial need of students and their families. Although no specific formula had been employed, colleges had previously taken both merit and need considerations into account in determining the allocation and size of scholarships [College Scholarship Service (1986), p. 4]. In support of the new need-based aid policy, the College Board, an association of colleges and universities, created the College Scholarship Service (CSS) to develop a formula for calculating need and to act as a central collection center for financial information on families of college applicants. Ostensibly to encourage research on the operation and application of the new system and on the funding of college education generally, the CSS also promoted communication of aid decisions among institutions through annual reports to CSS and through the formation of Overlap Lists or Overlap Groups [College Scholarship Service (1984), pp. 4-5].

Al the time the Justice Department began its investigation, the Overlap Group covering the elite northeastern colleges and universities consisted of twenty-three institutions: the Ivy League schools (Brown, Columbia, Cornell, Dartmouth, Harvard, Princeton, the University of Pennsylvania, and Yale), plus MIT, Amherst, Barnard, Bowdoin, Bryn Mawr, Colby, Mount Holyoke, Middlebury, Smith, Trinity, Tufts, Vassar, Wellesley, Wesleyan, and Williams. In addition to adopting common criteria for calculating need, members of the Group agreed to forswear merit scholarships and to meet annually to compare awards and resolve discrepancies in family contributions across institutions. Of the approximately 21,000 students admitted to these institutions annually at the time of the case, approximately half received some amount of financial aid. Of those, initial aid calculations for students accepted at more than one member institution would differ enough across schools to justify discussion of about 1,000 to 2,000 individual cases per year [Dodge (1989), p. A32]. Schools occasionally failed to reach agreement on aid packages, and the composition of aid packages could differ with 
respect to the amount of grant, loan, and work-study aid. Aid packages also covered only the first year of schooling; the size of later year awards was not coordinated.

Although previous news stories had reported on the Overlap Group's practice of coordinating financial aid awards [e.g., Butterfield (1983)], the Justice Department's interest in the Overlap Group appears to have been inspired by a Wall Street Journal article characterizing the Group's practices as a "price fixing system that OPEC might envy" [(Putka (1989)]. In August, 1989 the Justice Department began issuing civil investigative demands to the participating institutions and formally charged the Ivy schools and MIT with violating section 1 of the Sherman Act in May of 1991. The other fourteen non-Ivy Overlap Group colleges were not charged and, despite press reports and evidence presented at trial intimating that collusion on tuition and faculty salaries may have occurred as well [Putka (1992); Jaschik (1992)], the indictment was limited to the Group's financial aid practices.

The Ivy schools immediately signed consent decrees, leaving MIT the sole remaining defendant. In its defense, MIT argued (i) that Overlap's purpose was to assure that financial aid resources were allocated to the most needy students and (ii) that the charitable activities of nonprofit organizations did not constitute commercial behavior subject to the antitrust laws [MIT's Brief in Opposition to the Antitrust Division's Motion for Summary Judgement (1992), pp. 24-45); MIT's Post-Trial Memorandum (1992), pp. 6-9]. In September, 1992, the district court, rejecting as "pure sophistry" MIT's attempts to characterize financial aid as charity, ruled that the exchange of education for tuition was indeed a commercial activity and that aid coordination thus constituted a per se violation of the Sherman Act [U.S. v. Brown University et al. (1992)].

A year later, an appeals court unanimously reversed the lower court's ruling [U.S. v. Brown University et al. (1993)]. Two of the three judges agreed that tuition assistance was a commercial activity but ruled that the district court must consider possible "pro-competitive and social welfare justifications" for aid coordination under the rule of reason, while the third voted to dismiss the case on the grounds that financial aid was a charitable rather than commercial activity to which the Sherman Act was never intended to apply. In December of that year, MIT and the Justice Department announced a settlement under which colleges and universities would be allowed to exchange information about student financial need prior to awarding aid and to compare award levels retrospectively but would be forbidden to discuss or coordinate prospective awards to individual students.

\section{Traditional cartel theory}

A useful first step in assessing the merits of the Overlap Group's practices is to examine the strength of the argument against the coordination of financial aid. The 
economic objection to price fixing derives from the standard cartel model in which firms seek to increase their profits by agreeing to restrict output and raise price. But, as George Stigler advised, "collusion is impossible for many firms and collusion is much more effective in some instances than in others" (1964, pp. 44). Even if the analogy between educational institutions and commercial product manufacturers were sound, a number of conditions must be satisfied for collusion to succeed, among them, control of the relevant market, small numbers, homogeneous products, and barriers to external competition [Stigler (1964); Hay and Kelley (1974)].

Experience has corroborated the importance of these factors to cartel success. Historically, cartels have tended to form in concentrated industries and to control large market shares. In Hay and Kelley's (1974) survey of price-fixing conspiracies, cartelized industries tended to have four-firm concentration ratios well in excess of $50 \%$. Similarly, the cartels in Valerie Suslow's (forthcoming) study of legal international cartels controlled on average between 50 and $75 \%$ of the world market. Actual industrial cartels have typically had six or fewer members and have rarely contained more than ten participants [Hay and Kelley (1974); Suslow (forthcoming)]. The products involved, meanwhile, have tended to be relatively simple and homogeneous [Hay and Kelley (1974)]. Even in circumstances where cartels have been legal, formal attempts at collusion have focused overwhelmingly on basic commodities such as metals, chemicals, minerals, and raw materials [Suslow (forthcoming)].

The education market hardly fits this pattern. The Overlap Group consisted of only 23 of the 3400 accredited colleges and universities in the U.S. Member schools admitted approximately 21,000 freshmen in 1989 compared to 2.3 million new enrollments nationwide [U.S. Department of Education (1991), p. 177]. In other words, the Overlap Group served only about one percent of the market for new freshmen each year. Even if we limit the market to the nine northeastern states in which they operated, the Overlap Group accounted for less than five percent of new enrollments. By comparison, the University of California and California State system each account for approximately fifteen percent of new enrollments in California.

The Overlap Group, of course, comprised a much larger share of the still more narrowly defined market of elite northeastern colleges and universities. Nevertheless, member schools faced active competition from a significant number of quality institutions, both within and outside the northeast region. Well-positioned, extant competitors to the Overlap Group within the northeast include Bates, Bennington, Boston College, Brandeis, Hamilton, Haverford, Holy Cross, Leheigh, Skidmore, Swarthmore, Villanova, and Wheaton. Just outside the region are Bucknell, Johns Hopkins, Georgetown, and William and Mary, among others. Research universities within the Overlap Group also compete on a national level with private research universities like Chicago, Duke, Northwestern, and Stanford, and with top state universities like Berkeley, North Carolina, Michigan, and 
Virginia. Were education like the standard commodity of economic theory, the large number of active competitors in the education market would surely have restrained the ability of member schools to maintain prices above competitive levels for the more than thirty-year period over which the Overlap Group coordinated financial aid.

But even if barriers of some kind prevented external competition from undermining the cartel, competitive pressures within the Overlap Group should have strained collusive intentions. The primary effect of restricting price competition in heterogeneous product markets is to steer competitive efforts in other directions. Examples of such behavior from outside the realm of cartel behavior include flight frequency and amenity competition under air fare regulation and the use of resale price maintenance to stimulate dealer provision of free-ridable services. Again, if colleges behaved like firms, members of the cartel, having reached an agreement to set tuition levels above cost, would each have had an incentive to expand enrollments by offering a more desirable product. Nonprice competition, moreover, tends to dissipate the gains from collusion, thereby tempering the incentive to collude in the first place [Posner (1975)].

Given the destabilizing effects of nonprice competition, we would expect to see - had the purpose of aid coordination been anticompetitive - efforts by the Overlap Group to restrict and monitor nonprice aspects of education transactions as well as price. Even in the relatively homogenous product industries where cartels normally arise, collusive agreements routinely include "ancillary arrangements" such as market-allocation schemes and product-standardization and termsof-sale restrictions designed to inhibit nonprice competition [Posner (1970); Fraas and Greer (1977); Suslow (forthcoming)]. In contrast to the typical cartel product, education is a highly complex and heterogeneous commodity, a service rather than a good, the character and quality of which can be varied by altering, among other things, the quality of faculty, class sizes, access to and the diversity of course offerings, the number and naturc of nonacademic programs and social amenities, and the quantity and quality of educational, residential, and athletic facilities. Yet the Overlap Group focused exclusively on aid and made no attempt either to apportion the market or to restrain the efforts of member institutions to attract students by enhancing the nature or quality of educational services they offered. Given the mutability of the product, the most likely result of price collusion among universities would have been enhancement of the attributes that students consider most valuable.

Finally, the motive for collusion in the standard cartel model is pecuniary: Owners of for-profit firms can earn monopoly profits by cooperating to restrict output and raise price. The Overlap schools, however, like virtually all providers of higher education, are not-for-profit institutions, the distinguishing feature of which is the legal prohibition of distributing profits to anyone who controls or is a member of the organization [Hansmann (1980), p. 836]. To the extent that nonprofit status creates barriers to appropriating the gains from colluding, the 
incentive for collusion is diminished. Admittedly, stakeholders in educational organizations might appropriate those gains in other ways. Faculty and administrators, for instance, could realize supracompetitive profits through higher salaries or nonpecuniary compensation. ${ }^{2}$ But no one in a university gets to pocket the residual at the end of the day. Unlike owners of for-profit firms, stakeholders in educational institutions must capture the proceeds from collusion in indirect (and possibly subtle) ways.

Considered in light of standard cartel theory, the education market would thus seem singularly ill-suited to collusion. My contention is not that coordination did not take place; it clearly did for a period of over 30 years. Rather, the point is that the existence, behavior, and stability of the Overlap Group are hard to reconcile with conventional cartel theory. At a minimum, supporting a claim of anticompetitive effect requires substantial departures from the traditional model.

\section{The governance of higher education}

While cartel theory has been useful in informing antitrust policy toward horizontal restrictions, the theory was developed and operates best in conventional market settings. Cases involving nonstandard transactions or peculiar institutional or organizational arrangements call for a broader appreciation of the problems of economic organization and institutional choice. Thus, whereas cartel theory assumes the institutional structure under which parties exchange (markets and for-profit firms), the economics of organization analyzes the choice and implications of alternative institutional arrangements as an integral part of the problem facing transactors [cf. Coase (1972); Williamson (1992)]. In the context of higher education, the distinctive organizational features that need to be accounted for, in addition to aid coordination, are (i) the nonprofit status of suppliers and (ii) the rationing of education on the basis of the quality and performance of the consumer as well as by price. A persuasive explanation of aid coordination must be consistent with the organizational structure of the industry as well as with the salient economic attributes of education transactions.

\subsection{Nonprofit organization}

The economic theory of nonprofit organization holds that nonprofits are a response to the failure of for-profit and government organizations to meet ade-

\footnotetext{
${ }^{2}$ Note, however, that the claim that faculty benefitted from tuition collusion through higher salaries is inconsistent with intimations that universities also colluded on faculty salaries.
} 
quately demands for certain types of goods and services [Hansmann (1980); Weisbrod (1988)]. ${ }^{3}$ Where the costs to consumers of verifying the attributes of a product are high, the opportunity for pecuniary gain at the expense of poorly informed consumers provides for-profit suppliers the incentive to misrepresent quality. Consumers' ensuing distrust of quality representations by for-profit suppliers may result in an underprovision of the commodity [Hansmann (1980), pp. 843-4]. Similarly, some commodities with public-good dimensions, like cultural activities or environmental lobbying, may be undersupplied (relative to a particular group's preferences) because of the suspicion that donations to for-profit suppliers would be used to enrich the owners rather than for their intended purpose [Hansmann (1980), pp. 849-51]. Public provision breaks down, meanwhile, because the variety or level of services demanded does not generate sufficient political support to win public funding (Weisbrod, 1988). ${ }^{4}$ Nonprofits attenuate the problems associated with private provision by prohibiting the distribution of profits and thereby inhibiting the ability of administrators to benefit pecuniarily from opportunistic behavior at the expense of consumers.

Both the nature and range of the activities performed by universities favor nonprofit over for-profit governance. Basic research, for instance, could be supplied by for-profit enterprises spurred by property rights in their discoveries. But because of the value of broadly disseminating basic knowledge, we deny patent protection to basic discoveries and have chosen instead to cultivate the development of basic knowledge through not-for-profit institutions. Universities also receive donations (from both public and private sources) in their roles as cultural repositories and vehicles for a fairly broad range of social and charitable objectives. The willingness of individuals and institutions to make such contributions would undoubtedly be less without the legal impediments to misappropriation that nonprofit organization provides.

The nature of education, as a commodity, also poses organizational problems. As already noted, the quality of education is influenced by the size of classes, the diversity of course offerings, and the quality of facilities such as libraries and

\footnotetext{
${ }^{3}$ Much is made in the literature on nonprofits about the difficulty of defining the objective functions of schools and nonprofits more generally. The issue of an organization's objective function, however, is a red herring that acquires its odor from the convention of ascribing profit maximization to firms. Of course, only individuals literally have preferences. Rather than personifying organizations, the economics of organization regards organizations as structures for governing the process of realizing gains, resolving disputes, and effecting adjustments. Analytically, the problem becomes one of discovering the substantive problem the parties wish to solve, identifying the practical barriers preventing that solution from being realized, and distinguishing and comparing alternative responses to those barriers.

${ }^{4}$ In the context of education, elite or religious colleges and universities are less likely to attract broad public support and thus more likely to be private.
} 
laboratories. In choosing a school, students or their parents must make judgements regarding the relative quality of faculties, the merits of alternative curricula, and the conduciveness of the overall learning environment supplied by each. The quality of one student's education, moreover, depends on the intelligence and backgrounds of other students admitted to the institution. In this sense, students are inputs into the educational process as well as the principal consumers of educational services [cf. Rothschild and White (1991)].

The complexity and subtlety of education services make it difficult to evaluate all of the relevant dimensions of the product ex ante. ${ }^{5}$ Indeed, students are defined by their lack of knowledge about the substance of the product they are about to receive. At best, an applicant can develop only a broad and superficial sense of the attributes of a particular institution prior to attendance and, even after graduation, may have difficulty assessing a college's actual contribution to the development of his human capital: As with all capital decisions, investments in human capital are made in highly uncertain environments, and the realized value of those investments is contingent on the evolution of events. A nonexpert is unlikely ever to gain the competence to assess the vast array of decisions affecting educational quality. Was the quality of instruction as good as it could have been? Was the library staff suitably knowledgeable and supportive in light of the resources available to it? Were resources allocated appropriately across departments and support services? Were applicants screened carefully and the best students admitted? These and other questions regarding the quality of an education can often only be answered by the individuals supplying the service [compare Weisbrod (1988), p. 46]. Finally, a long lag - typically four years - exists between selecting an institution and acquiring the "product." The time involved obtaining an education generally precludes sampling the offerings of a large number of institutions. The ability to transfer patronage to a rival supplier, meanwhile, is limited once trade has begun. Accordingly, the typical consumer in the market for higher education services makes a one-time purchase from a single supplier.

The possibilities for opportunism are great where measurement and switching costs are high. In purchasing an education, consumers must rely heavily on the judgement and goodwill of the supplier with regard to the consumer's needs and

\footnotetext{
${ }^{5}$ Compare Hansmann (1980): "education... is a complex and subtle service, and in many cases a parent or a student may not feel competent to make adequate judgements about the quality of the teaching and facilities that an institution offers" (p. 866); and Bok (1991): "students (and their parents) cannot easily judge the quality of the education they will receive in different colleges and universities" (p. 311). Milgrom and Roberts. (1992) chose education to illustrate the difficulties of complete contracting (pp. 127-129).
} 
the configuration of the services. An unscrupulous operator could misrepresent or chisel on quality dimensions that are difficult to verify. Educators could effect "buy ins" by offering large initial financial aid packages but small "follow on" packages. The admissions process also presents occasions for opportunism: Administrators of for-profit colleges might profit by admitting high-willingness-to-pay students over higher quality applicants. Given the unavoidability of legitimate errors in the admission process, fellow students would find it difficult to determine whether the quality of a particular student was a poor draw or an opportunistic admission or, more gencrally, whether the student body ovcrall represented the best available given the applicant pool. The private value to a less capable student of being confused with qualified matriculants, however, may be substantial.

Contractual promises of quality in such an environment offer little security. In the first place, it would be impossible to enumerate all the dimensions of an education and to identify and describe appropriate responses to changing circumstances. But even if such a contract could be written, identifying malfeasance and assessing damages for breach would be virtually impossible.

Were such problems to arise in intermediate product markets, a likely response would be integration of production. Integration reduces the incentive to behave opportunistically by, among other things, attenuating the link between the supplier's actions and rewards [see Williamson (1986), p. 140]. Integration or self-production of higher education, as with many other consumer goods, is not a practical option, however. In such circumstances, nonprofit organization serves, in effect, as a substitute for integration. ${ }^{6}$

\footnotetext{
${ }^{6}$ The correspondence in purpose and effect between nonprofit organization and integration is reflected in the legal status of decisions made by college officials and corporate directors. Although current courts view the relationship between students and colleges as contractual, courts also afford colleges far more discretion to adapt to change than they do participants in standard commercial transactions. Rather, decisions of academic officials are treated like those of corporate directors or others acting in a fiduciary capacity. In disputes between students and colleges, courts have repeatedly underscored the need to permit educators broad discretion to exercise their expertise and have generally refrained from interfering unless a decision is shown to be arbitrary or capricious [see Board of Curators of the University of Mississippi v. Horowitz (1978).] Accordingly, college officials possess wide latitude to design or alter programs, set academic standards, evaluate performance, and discipline conduct [e.g., Colleges and Universities (1976)]. This so-called doctrine of academic abstention is virtually identical to the business judgement rule for corporations under which directors are granted discretion to manage the corporation without judicial review, unless there exists "a disabling conflict of interest" such as self dealing [Hamilton (1987), pp. 310-311); Clark (1985), pp. 73)]. Hence, corporate directors, like administrators of nonprofits, are also subject to a form of nondistribution constraint. The unifying concerns are (i) the need to rely on others' expertise and judgement to carry out the effective administration of the organization and (ii) the opportunities this creates to exploit that discretion, which motivates limitations on the ability to profit therefrom.
} 
The economic role of nonprofits in the provision of education has two implications for the present analysis. First, by reducing the incentive for colleges to act opportunistically in their relations with students and benefactors, nonprofit organization also attenuates the pecuniary incentive for collusion. If the constraint on the distribution of profits is effective, a motive other than the desire to obtain monopoly rents must underlie the coordination of financial aid. Second, conclusions derived from cartel models predicated on profit maximization may not apply where decision makers are constrained to spend the proceeds of collusion in ways compatible with legitimate functions of the organization. To the extent rents are spent enhancing the quantity and quality of services provided, collusion among nonprofits may actually improve the allocation of resources in markets subject to acute market failures. A skeptic might contend that nonprofit organization is merely a legal fiction that cloaks, but does not alter, the profit motives of stakeholders in educational organizations. But those who challenge the theory of nonprofits assume the burden of providing an alternative explanation that coheres with the selective adoption of the nonprofit form. ${ }^{7}$ In the end, the effectiveness of the nondistribution constraint in general and the proposition that Overlap faculty or administrators earned excess returns on their human capital in particular are empirical questions open to confirmation or refutation (see section 4 below).

\subsection{Financial aid coordination}

If not to earn monopoly rents, then what purpose did financial aid coordination serve? The answer offered here is that aid coordination was necessary to support the policy of need-based financial aid. But before turning to that argument, we need first to consider the motivations and implications of a financial aid policy based on need.

\subsubsection{Need-based aid}

Stratification. In both its human capital and signalling roles, education will tend to be more efficiently provided if students are stratified among colleges by ability. First, teaching is easier and more effective when students are relatively similar in ability [cf. Rothschild and White (1991), pp. 3, 11]. Second, education will provide a cleaner signal of ability to potential employers if the quality of students

\footnotetext{
${ }^{7}$ The argument that the nonprofit form is chosen for its tax advantages merely moves the question one step further back: why has society chosen to confer tax advantages on nonprofit organizations? On the tax implications of nonprofit organization, see Hansmann (1980), pp. 881-883). The tax argument also fails to explain variations in the use of nonprofits across industries.
} 
is relatively homogeneous. An individual student's quality thus has external effects on the value of the education received by his classmates. ${ }^{8}$

To understand the effects of price competition on the allocation of students to schools, consider a situation in which the quality of a student's education depends only on the average quality of students attending a particular institution. Specifically, suppose that each school has capacity for $\mathrm{N}$ students and that the quality ranking, $r$, of each school depends on the average quality of its students, who are themselves ranked by ability indexed by $i$ (where 1 denotes the highest ranking). Also assume for the moment that each student has the same willingness to pay for an education of a given quality. A simple admissions and pricing arrangement that would assure the full stratification of students among schools by quality is one in which (i) all schools charge the same tuition, and (ii) each school accepts all students for which $\mathrm{i} \leq \mathrm{rN}$. In other words, school 1 accepts all applicants ranked between 1 and $N$, school 2 accepts all applicants ranked between 1 and $2 \mathrm{~N}$, and so on. Under this scheme, students ranked between 1 and $\mathrm{N}$ would be accepted at all schools to which they apply, while students ranked $N+1$ to $2 \mathrm{~N}$ would be accepted at all but the top school, et cetera. Since tuition is the same regardless of the school a student attends, each student can do no better than to attend the highest ranked school to which he is accepted. The resulting allocation of students will therefore be fully stratified across schools in the sense that, for every student, the school attended by student $i$ is ranked higher than the school attended by student $i^{\prime}$ only if $i<i^{\prime}$. ${ }^{9}$

Suppose now that students differ in their willingness-to-pay for an education so

\footnotetext{
${ }^{8}$ See Hansmann (1986) for an analysis of "status" organizations in which each member's utility is affected by the status of other members. Note that the externalities emphasized in the text derive from human capital production and signalling efficiencies, although students may also have direct preferences over the characteristics of fellow students. Note also that benefits may also arise from huving a student body with diverse backgrounds and talents [see Rothschild and White (1991)]. To the extent that the benefits of such attributes are imperfectly correlated with academic ability, preferences for diversity introduce an additional tradeoff that would tend to offset the benefits of strict stratification of students by ability. Nevertheless, because of the production and signalling benefits of stratification, education will still be more efficiently provided if, within each set of students with common backgrounds and talents, students are allocated among schools by academic ability. Thus, even where diversity in nonacademic dimensions has value, the efficient allocation of students among schools is likely to involve a general, though not perfect, stratification of students by academic ability.

${ }^{9}$ Notice that this admissions scheme requires students to know the ranking of schools but not their own ranking relative to other students. The problem of college admissions is also the subject of an extensive game theoretic literature on matching [see, for instance, Roth (1985) and Roth and Sotomayor (1989)]. However, the results of this literature, which also addresses the problems of sorority rush (Mongell and Roth, 1991) and medical intern allocations (Roth, 1984), depend on the assumption that students have preferences over schools but not over other students [see, for instance, Mongell and Roth (1991), p. 458)]. One of the remarkable features of Overlap was that it promoted stratification of students without the need for the relatively complicated algorithms sororities and hospitals devised to allocate rushees and interns.
} 
that some students are unwilling or unable to pay the uniform tuition level schools have set and would therefore choose not to attend college (or, more realistically, would choose to attend a much lower ranked school than they are qualified for that does not participate in this pricing scheme). Setting a tuition level to "clear the market" for enrollments to a particular school would eliminate some high ability but low-willingness-to-pay students from the applicant pool and thus result in the admission of some lower ability but high-willingness-to-pay applicants. A modification to the previous arrangement that would maintain the pool of quality matriculants to the top schools is to offer "discounts" off list tuition to low-willingness-to-pay students. As long as schools offered each student the same discount, students would still choose to attend the highest ranked school to which they were accepted and the allocation of students would continue to be stratified. Under the assumptions so far, tuition discounts represent pure transfers.

Local public goods. In actuality, however, the loss of tuition revenue entails opportunity costs by reducing the resources available for other educational inputs such as faculty, facilities, and programs. With few exceptions, these other inputs have the character of local public goods in that augmenting their quality or quantity for one student benefits the entire educational community. Since local public good attributes cannot be personalized, individual students do not have an incentive to bargain efficiently for their provision; each student has an incentive to negotiate the best tuition deal possible for himself and free ride on other students' payments for local public inputs, resulting in a classic underprovision problem. ${ }^{10}$

The theoretical solution to such externality problems is to price public goods according to each individual's willingness to pay [e.g., Atkinson and Stiglitz (1980), p. 509]. As a practical matter, however, the implementation of that solution is often hindered by (i) the difficulty of identifying each customer's willingness to pay and (ii) the inability to discriminate in price among customers in the face of competition. In the context of education transactions, every student would wish to represent himself as a low willingness-to-pay student. If schools were unable to separate true low-willingness-to-pay students from those simply seeking a better deal, schools might find it better to offer no discounts at all - and lose some true high-ability, low-willingness-to-pay students - than to reduce

\footnotetext{
${ }^{10}$ See, for instance, Oakland (1974); and more generally, Atkinson and Stiglitz (1980), ch. 17. In commercial contexts, competition for the marginal customer may lead to an inefficient supply of nonprice product attributes where there are variations in the valuations customers place on product attributes [Spence (1975)] or systematic correlations between search costs and reservation prices [Winter (1993)]. James and Rose-Ackerman (1986) discuss nonprofits as a solution to problems in the provision of local-public goods (pp. 55). Hansmann (1986) shows that, where individuals' status confers externalities on others, efficiency is likely to require both stratification of individuals among organizations by quality and some form of cooperative organization. [Also see Rothschild and White (1991).] Hansmann (1980) also suggests that merit scholarships would serve to internalize individual externalities and make stratification unnecessary but that "merit scholarships are the exception and not the rule" (p. 121). The analysis here, in contrast, suggests that need-based aid supports stratification.
} 
expenditures on other inputs. Ultimately, the inability to price discriminate among students will lead either to less stratification of students or less efficient levels of expenditures on the local public-good attributes of education.

In this light, a policy of basing financial aid awards exclusively on need can be seen to offer a simple, easily-implementable solution to both the public-goods and stratification problems. To the extent that wealth and willingness to pay for education are positively correlated, need-based aid attenuates the free-rider problem by making the price paid for an education an implicit function of a student's willingness to pay. At the same time, need-based aid supports need-blind admissions. By tilting admissions criteria toward ability over wealth, a need-based aid policy permits some lower-income students to attend the highest-quality institution for which they are qualified. Holding school size constant, admission of these students would displace some lower-quality but higher-income applicants, who would then become part of the applicant pool for lower-status institutions. Need-based aid thus tends to increase stratification of schools by student quality and decrease stratification by wealth. ${ }^{11}$

\subsubsection{Internal coordination}

The preceding solution to the public-goods and stratification problems in education could not be sustained, however, in the face of unrestricted competition. A school that attempted to institute a need-based aid policy unilaterally would find its program steadily eroded as other schools lured away the most desirable students by offering merit awards. From this perspective, efforts to improve the quality ranking of an institution by attracting better students from higher-ranked schools with merit scholarships constitute a form of rent seeking. Although the order in which academic institutions are ranked is irrelevant to society as a wholc, price competition for individual students involves an externality that could lead an individual school to try to lure away high ability students even if the existing allocation was efficient: While the private cost to a given school of attracting a high quality student from a higher-ranked institution through merit aid is the reduction in funds available for other inputs, in gaining that student, the school

\footnotetext{
${ }^{11}$ In addition to its potential efficiency effects, a need-based aid policy, by redistributing aid resources from high-ability, high-income students to lower ability and less affluent applicants, may also serve the redistributional preferences of university patrons. A shift from merit- to need-based aid may also influence the study incentives of high school students, although the direction of this effect is not clear a priori. On the one hand, the elimination of merit-based scholarships reduces a direct financial incentive to study and excel in high school. On the other hand, the greater selectivity and stratification of schools in quality dimensions under a need-based aid policy may make the return to getting into a better school that much greater. Finally, need-based aid may also affect income production and investment incentives for parents with school age children [Feldstein (1992)].
} 
also imposes a cost on the institution that loses the student. ${ }^{12}$ The latter school must either accept the loss of the student or reallocate resources from other purposes to merit aid. Again, the outcome of price competition for individual students will be less stratification of students by quality or, if colleges respond in kind to merit-based awards from competing institutions, in the underprovision of public-good educational attributes.

To prevent competition for individual students from subverting the benefits of a need-based aid policy, schools would therefore have to agree collectively to foreswear merit scholarships. Such an accord, moreover, would have to be supported by governance structures to guarantee compliance. In particular, a mechanism to coordinate and police aid offers is necessary to assure merit awards are not disguised as need-based aid.

\subsubsection{External competition}

In principle, competition from schools outside the Overlap Group would threaten need-based aid in the same way as competition from within the Group. Lower-ranked Overlap schools, in particular, would be expected to face pressures to offer merit awards to compete with proximately ranked schools outside the Group. Efficiency explanations for the Overlap Group's practices must, like the standard collusion model, come to terms with the existence of external competitors.

An explanation for the stability of the Overlap Group again lies in the quality distribution of students and stratification of schools. Generally, the statistical frequency of students of a particular quality or ability level will be less the further that quality from the mean. Thus, in a finite population of students, the expected difference in quality between rank-ordered students will diminish as quality approaches the mean. Correspondingly, the quality stratification of schools that enroll students from the upper end of the quality distribution will be greater than for schools further down in rank. Instead of competing "vertically" to attract students of higher rank from higher-status schools, lower-status schools are thus more likely to compete "laterally" to attract students from the (relatively large) pool of individuals with similar but lesser ability. As the number of students and schools clustered at a particular quality level increases, the stratification and public-goods problems identified above become less pronounced. With a large number of students of similar ability, students become near-perfect substitutes; a student lost to another school can be replaced with a comparable student from the available pool. In that event, one school's admissions do not affect another's

\footnotetext{
${ }^{12}$ The ban on merit aid has a counterpart in the local public finance context in legislation in some states such as Michigan that prohibits companies from relocating from one municipality to another without permission of the original municipality when the inducement to move was special tax treatment from the new locale. In effect, the law prohibits competition for individual companies while permitting competition in overall tax rates and community-wide services.
} 
quality and there is no externality. Also, as the number of suppliers increases relative to the dispersion of preferences for local-public good characteristics among customers, the ability of individual suppliers to span the characteristics space through specialization increases. Generally, the likelihood of existence and efficiency of competitive equilibria for the provision of local-public goods increases the larger the number of suppliers relative to the number and diversity of consumers [see, for instance, Atkinson and Stiglitz (1980)]. With less need (and ability) to discriminate on the basis of willingness to pay, such schools would then be expected to compete more dircetly in conventional tuition and quality dimensions and to devote smaller portions of their budgets to need-based financial aid.

The point at which the nature of competition among schools changes and, thus, the optimal size or inclusiveness of the Overlap Group are empirical issues. According to Derek Bok, "among the many hundreds of independent colleges, the number that truly admit all deserving applicants regardless of means has probably declined to 10 or $20^{\prime}$ [Bok (1991), pp. 326]. If the financial capacity to offer need-blind admissions represents a meaningful threshold, then it is entirely conceivable that competition among the 23 elite northeastern colleges that made up the Overlap Group was qualitatively different from competition both with and among schools outside of the Group.

\section{Assessment}

Although differences in the nature of competition between elite and lesser schools appear consistent with an efficiency interpretation of aid coordination, such differences might also create barriers capable of supporting collusion for anticompetitive purposes. For assessing the merits of the Overlap Group's practices and for its contribution to our understanding of organization of the education industry more generally, we would like to be able to distinguish between these competing interpretations empirically. The ideal test would establish whether Overlap led to a more or less efficient allocation of educational resources and students. Whereas standard cartel theory predicts a reduction in output, an increase in the quantity and quality of educational services should be the result if coordination served efficiency purposes. Unfortunately, the practical problems with performing such a test appear insurmountable. Simple measures of educational output such as enrollments or degrees conferred would obviously be inadequate given the heterogenous nature of education services. On the other hand, the same intractable measurement problems argued to motivate the use of nonprofit organization in the first place are likely to frustrate attempts to devise more sophisticated measures of educational output.

It seems unlikely, in any event, that Overlap reduced output in the conventional sense. Indeed, the government made no such claim, pointing instead to the possibility that aid coordination led to a misallocation of students among schools. 
Specifically, the government complained that the absence of merit scholarships could have led to an inefficient allocation of students by inducing some high-ability students to attend non-Overlap colleges [Government's Trial Brief (1992), pp. 41-42]. Although neither the government nor MIT chose to address the issue of student allocations analytically, the government supported its allegations with evidence that some highly qualified students accepted at Overlap institutions chose instead to attend non-Overlap universities [Trial Testimony (1992), pp. 659-665]. Such evidence, however, clearly fails to dispose. If the externalities associated with student quality featured prominently in the analysis of this article are important, evidence of the loss of some high-quality students to non-Overlap schools offering merit awards could actually be construed to support expansion of the Overlap agreement. More generally, some qualified students are likely to choose non-Overlap schools under any practical pricing arrangement. The relevant question in assessing the effect of Overlap on the allocation of students, therefore, is whether financial aid coordination led to a better or worse allocation of students and educational resources on net. Given the dominance and unique position of the Overlap Group in the strata of educational institutions and the practice's thirty-year duration, neither cross-sectional nor time-series comparisons are likely to help establish the counterfactual. ${ }^{13}$

Perhaps because of these conceptual and practical obstacles to testing the efficiency implications of Overlap, both the government and MIT sought to bolster their cases by evaluating the effects of financial aid coordination on price. For its part, the government. produced expert testimony that aid coordination raised the price that at least some students paid for an Overlap education [Trial Testimony (1992), pp. 667-694]. MIT's expert witness responded with an extensive crosssectional analysis of the determinants of net tuition demonstrating that, on average, net tuition levels (tuition less aid) at Overlap and non-Overlap schools were not significantly different [Trial Testimony (1992), pp. 1619-1639; Carlton, Bamberger, and Epstein (1992)]. Overlap was, according to MIT, "revenue neutral;"

\footnotetext{
${ }^{13}$ In principle, the demise of Overlap might permit evaluation of Overlap's effects using time-series analysis. The theory predicts that collapse of Overlap will lead, at least in the short term, to less stratification among schools. Of course, schools harmed academically or financially by deviations from a need-blind policy would be expected to modify their admissions policies in response. Over the longer term, the discontinuation of aid coordination would therefore most likely show up as a reduction in resources available for expenditures on other educational inputs. Some preliminary accounts support the existence of the externality identified in the text in operation. Unannounced deviations from need-blind admissions by some top Ivies have been alleged to have resulted in a greater percentage of low-income students in the entering classes at Ivies that adhered to a need-blind admissions policy, which, if true, should appear as increased aid costs at schools that maintained need-blind admissions and reduced aid costs at those that did not. The difficulty of documenting which schools retained and which abandoned need-blind aid impedes verification of this allegation, however. In addition, the settlement arrived at between the Justice Department and MIT reinstated a weakened form of aid coordination, further complicating the analysis.
} 
the higher prices paid by some students were completely offset by lower prices (increased aid) for others. A program whose sole effect was to redistribute financial aid resources, MIT argued, does not conflict with the efficiency objectives of the antitrust laws [Carlton, Bamberger, and Epstein (1992), pp. 23-24; 34].

The rationale for analyzing price - namely, that higher prices deter efficient transactions - does not readily extend to the circumstances in the education market, however. First of all, we know from general principles that analyses of average pricc say little about cfficiency where complex pricing schemes, such as multi-part pricing and price discrimination, are employed. A finding that Overlap increased average net tuition could be consistent with collusion or with the hypothesis that financial-aid coordination allowed discrimination in prices that supported either more efficient student stratification or the enhancement of facilities, programs, and other educational amenities of value to students and university patrons. Furthermore, the fact that Overlap schools found it possible and desirable to coordinate financial aid while other schools with similar objectives did not suggests that Overlap schools were distinct from their non-Overlap counterparts. To the extent that membership in the Overlap Group was an endogenous institutional response to factors unique to that set of institutions, cross-section regressions of price on membership in Overlap risks confounding the effects on price of participation in the Overlap group and of the exogenous variables that motivated participation [see, generally, Heckman (1979); and for an application to governance choice problems, Masten (1993)]. If, as the argument in section 3.2 suggests, the noncooperative pricing equilibria for Overlap and non-Overlap schools differ, the behavior of non-Overlap institutions provides an inadequate benchmark for assessing the cooperative pricing behavior of Overlap schools.

A final distinction between the anticompetitive and efficiency interpretations of aid coordination regards the motives for collusion. Although no one owns a nonprofit, faculty might appropriate the benefits of collusion through higher salaries. The economic theory of nonprofits, on the other hand, holds that the nonprofit form exists precisely to temper the pecuniary incentive for opportunism and thereby to increase the confidence of consumers and benefactors that payments and donations will be used in their interest. If the nondistribution constraint is effective, quality-adjusted faculty salaries and other compensation should be no higher at Overlap schools that at comparably ranked non-Overlap institutions.

A look at average salaries and compensation of faculty at Overlap and non-Overlap colleges and universities provides some evidence on this question. The data used here are for the 1987-88 academic year, the most recent period prior to the start of inquiries into the Overlap Group practices. To provide as similar a comparison group as possible, I restricted the sample to Overlap Group institutions plus non-Overlap schools listed among the top twenty-five universities by U.S. News and World Report in its 1987 annual ranking (U.S. News and World Report (1987), pp. 53, 55). The non-Overlap research universities consisted of 
Berkeley, Duke, California Institute of Technology, Chicago, Emory, Illinois at Champaign-Urbana, Johns Hopkins, Michigan, North Carolina, Northwestern, Rice, Stanford, Texas at Austin, Virginia, Washington at St. Louis, William and Mary, and Wisconsin. The non-Overlap liberal arts colleges were Carlton, Centre College, Claremont McKenna, Colorado College, Davidson, Earlham, Grinnell, Hamilton, Haverford, Pomona, Oberlin, Reed, St. John's, St. Olaf, Swarthmore, and Washington and Lee. Missing data for Dartmouth, Emory, Middlebury, St. John's, and Wellesley reduced the sample to 51 institutions. The fact that educational rankings rarely go deeper than twenty or twenty-five institutions is consistent with the claim made earlier that stratification is greater and more important in the upper tail of the distribution. At lower levels, schools tend to be clustered in "tiers" of comparable schools.

A simple comparison of average salaries and compensation of faculty at Overlap Group institutions and at other top-ranked colleges and universities shows that the pecuniary compensation of faculty at Overlap and non-Overlap schools were virtually identical (see Table 1). Indeed, to the extent that state per capita income mirrors cost of living differences, real salary and compensation of Overlap faculty appear to be somewhat lower than that of their non-Overlap peers. Table 1 also reveals, however, that Overlap schools differ from other top-ranked educational institutions in size and the quality of students and in their institutional character and affiliations. ${ }^{14}$

To control for variations in institutional characteristics that might correlate with faculty compensation, I regressed average salary and compensation for all faculty and by faculty rank on institutional attributes (see Table 2). The overall quality of an institution is likely to be reflected in the quality of its student body, measured here by the percentage of entering students with SAT scores at or above 700 . In addition, because faculty in scientific or technical fields tend to earn more than their counterparts in humanities, average salaries are likely to be higher at schools that altract and admit a greater proportion of students with quantitative and technical interests and proficiencies. We might also expect faculty at research universities to earn more than their counterparts at liberal arts colleges. Other control variables include the number of full-time faculty, categorical variables for public universities and for colleges with religious affiliations, and state income as a proxy for regional cost-of-living differences. Although the results are generally consistent with previous studies of the determinants of faculty salaries [see, for instance, Guthrie-Morse et al. (1981); Barbezat (1989)], the results continue to provide no evidence that Overlap enriched faculty pecuniarily.

\footnotetext{
${ }^{14}$ Overlap schools are also more selective as measured by their acceptance and enrollment rates. Overlap schools, on average, accept about 35 percent and enroll about 15 percent of applicants compared to 45 and 20 percent for the non-Overlap schools in the sample. Carlton et al. (1992) report the acceptance rate for all non-Overlap schools as 68 percent. Including acceptance and enrollment rates in the salary and compensation estimations does not affect the other results qualitatively.
} 
Table 1

Faculty compensation and school characteristics

\begin{tabular}{|c|c|c|c|c|}
\hline & & $\begin{array}{l}\text { Combined } \\
(n=51)\end{array}$ & $\begin{array}{l}\text { Overlap } \\
(\mathrm{n}=21)\end{array}$ & $\begin{array}{l}\text { NonOverlap } \\
(\mathrm{n}=30)\end{array}$ \\
\hline \multicolumn{5}{|c|}{ A. Continuous variables (means and standard deviations) } \\
\hline Salaries ${ }^{a}$ & average salary of full-time faculty & $\begin{array}{l}\$ 44,373 \\
(7,052)\end{array}$ & $\begin{array}{l}\$ 44,200 \\
(6,291)\end{array}$ & $\begin{array}{l}\$ 44,619 \\
(7,640)\end{array}$ \\
\hline Compensation $^{a}$ & salary plus major fringe benefits ${ }^{c}$ & $\begin{array}{l}\$ 54,263 \\
(8,395)\end{array}$ & $\begin{array}{l}\$ 53,763 \\
(7,425)\end{array}$ & $\begin{array}{l}\$ 54,976 \\
(9,103)\end{array}$ \\
\hline SAT700V ${ }^{b}$ & percent of students with verbal SAT score $\geq 700$ & $\begin{array}{l}12.1 \\
(9.1)\end{array}$ & $\begin{array}{l}15.8 \\
(10.3)\end{array}$ & $\begin{array}{l}9.4 \\
(7.2)\end{array}$ \\
\hline SAT700M $^{b}$ & percent of students with math SAT score $\geq 700$ & $\begin{array}{l}28.0 \\
(18.3)\end{array}$ & $\begin{array}{l}30.9 \\
(18.4)\end{array}$ & $\begin{array}{l}26.1 \\
(18.3)\end{array}$ \\
\hline FACSIZE ${ }^{\text {a }}$ & number of full time faculty & $\begin{array}{l}518 \\
(488)\end{array}$ & $\begin{array}{l}444 \\
(346)\end{array}$ & $\begin{array}{l}570 \\
(567)\end{array}$ \\
\hline INCOME ${ }^{d}$ & state per capita income & $\begin{array}{l}\$ 12,754 \\
(1,613)\end{array}$ & $\begin{array}{l}\$ 13,690 \\
(1,670)\end{array}$ & $\begin{array}{l}\$ 12,100 \\
(1,218)\end{array}$ \\
\hline \multicolumn{5}{|c|}{ B. Categorical variables (observations) } \\
\hline UNIVRSTY $^{b}$ & $\begin{array}{l}=1, \text { if university } \\
=0, \text { if college }\end{array}$ & $\begin{array}{l}25 \\
26\end{array}$ & $\begin{array}{l}9 \\
12\end{array}$ & $\begin{array}{l}16 \\
14\end{array}$ \\
\hline RELIG $^{b}$ & $\begin{array}{l}=1, \text { if religious affiliation } \\
=0, \text { otherwise }\end{array}$ & $\begin{array}{l}5 \\
46\end{array}$ & $\begin{array}{l}0 \\
21\end{array}$ & $\begin{array}{l}5 \\
15\end{array}$ \\
\hline PUBLIC $^{b}$ & $\begin{array}{l}=1, \text { public institution } \\
=0, \text { private institution }\end{array}$ & $\begin{array}{l}8 \\
43\end{array}$ & $\begin{array}{l}0 \\
21\end{array}$ & $\begin{array}{l}8 \\
22\end{array}$ \\
\hline
\end{tabular}

a Source: American Association of University Professors Annual Survey on the Economic Status of Professors, 1987-88, Academe, March-April 1988.

b Source: Barron's Profiles of American Colleges (16th ed.)

c Major fringe benefits include Social Security and retirement contributions; medical, life and dental insurance; disability income protection; unemployment and worker's compensation; tuition for faculty children; and other miscellaneous benefits with cash alternatives.

d Source: Statistical Abstract of the United States.

Faculty quality, of course, is also likely to influence faculty salaries. But as with educational quality, faculty attributes such as research productivity and teaching ability are difficult to quantify, and data that would permit estimation of appropriately controlled earnings equations for Overlap and non-Overlap faculty do not exist. ${ }^{15}$ The bias from failing to control for faculty quality, however, works in favor of finding a positive effect of Overlap membership on compensation to the extent that the quality of faculty at Overlap institutions is at least as great as that of non-Overlap faculty.

Finally, the results do not preclude the possibility that faculty at Overlap

\footnotetext{
${ }^{15}$ Existing surveys of individual faculty salaries contain only a small sample of the set of colleges and universities and do not identify individual institutions [see Barbezat (1989)]. Though suitable data is not publicly available, antitrust authorities presumably could obtain such information as part of their investigation.
} 


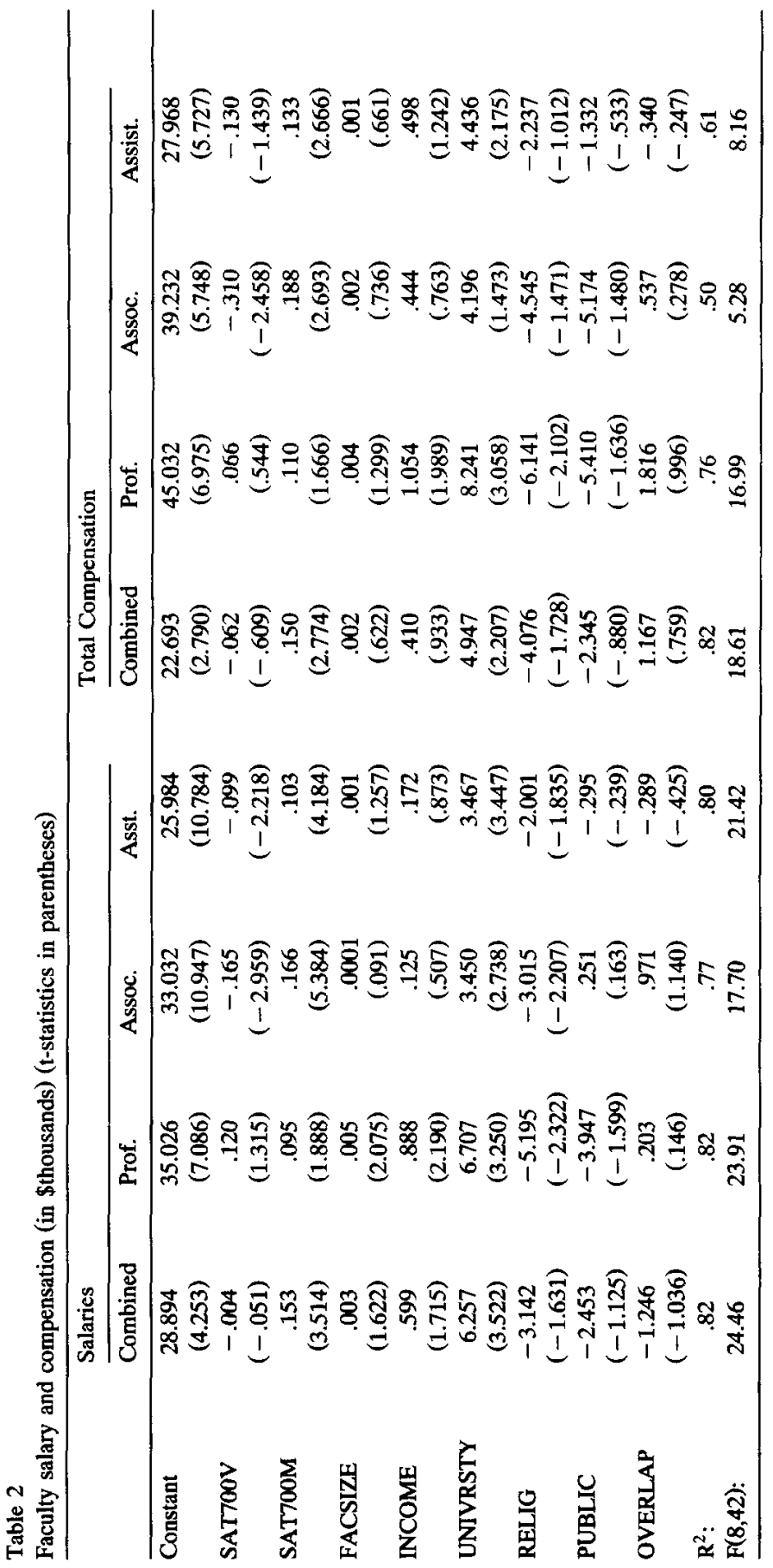


institutions benefitted from aid coordination through nonpecuniary compensation. Cartel theory does not explain, however, why faculty at Overlap schools would choose to take a greater proportion of their income in nonpecuniary forms than do their peers at non-Overlap schools. Furthermore, most of the nonpecuniary attributes that faculty value - course-load reductions for research, better libraries and laboratories, modern computing equipment, greater staff support - are inputs into the educational process. As argued in section 3, the nonprofit form serves precisely to assure that receipts of the organization are expended on activities compatible with its legitimate purposes. The fact that whatever gains there may have been to aid coordination appear not to have been distributed as faculty salaries thus supports the role ascribed to nonprofit organization and aid coordination in this paper.

\section{Conclusion}

From an economic perspective, the relevant issue in antitrust cases is whether the practice in question increased or decreased efficiency. As a practical matter, however, we are rarely able to assess the efficiency of a given practice directly, a problem that becomes even more acute where the good or service in question is complex and not easily quantified. Thus, the variables traditionally scrutinized in antitrust inquiries - prices, cross elasticities, and entry barriers - tell us nothing directly about efficiency in a market but help only to establish whether observed circumstances and outcomes conform to the assumptions and implications of our theoretical models. By drawing analogies between the facts of the case and deductive models, we hope to infer the purpose and effect of the behavior in question.

In developing its case against the Overlap Group, the government, emphasizing the commercial nature of education transactions, sought to draw just such an analogy. On examination, however, circumstances in the market for higher education prove hard to reconcile with the standard cartel model that forms the economic rationale for legal prohibitions of collusion. In contrast, the efficiency interpretation of Overlap developed here is fundamentally compatible with the distinctive economic and institutional features of the education industry. In particular, nonprofit organization, nonprice rationing of education at elite institutions, the contemporaneous formation of Overlap and adoption of aid policies based exclusively on need, the absence of restrictions on nonprice competition, the exceptional longevity of the Overlap Group, and the apparent absence of pecuniary gains from the agreement are all consistent with an interpretation of Overlap as a solution to problems inherent in the provision of higher education.

The actual posture of the antitrust laws toward horizontal restrictions by nonprofits remains unsettled [see Salop and White (1991), and U.S. v. Brown University et al. (1993)]. Although U.S. courts have repeatedly affirmed the 
applicability of antitrust laws to nonprofit entities, they have also grudgingly acknowledged differences between the nature and objectives of for- and nonprofit organizations and the need to tailor the law's application to nonstandard transactions and organizational forms. Accordingly, horizontal restrictions that would be illegal per se if adopted by for-profit firms have been subjected to a more tolerant rule-of-reason analysis when employed by nonprofits or in other nonstandard settings [see Goldfarb v. Virginia State Bar (1975); American Society of Mechanical Engineers, Inc. v. Hydrolevel Corp. (1982); Broadcast Music, Inc., v. Columbia Broadcasting Systcm (1979); and U.S. v. Brown University et al. (1993)]. And whereas courts have generally attempted to exclude from consideration factors other than a restriction's effects on competition [the classic case being National Society of Professional Engineers v. United States (1978)], they have demonstrated a greater willingness in cases involving nonprofits in general and educational institutions in particular to weigh "noneconomic" objectives in evaluating the reasonableness of particular restrictions [see NCAA v. Board of Regents of the University of Oklahoma (1984), pp. 2971, 2978-2979].

Nevertheless, exceptions to the per-se rule for noncommercial organizations and unfamiliar arrangements have evolved in a piecemeal fashion, and the criteria courts will employ in rule-of-reason analyses remain ambiguous. The Overlap case illustrates the advantages of expressly adopting a more "direct approach" to assessing behavior where nonstandard transactions or peculiar institutional or organizational arrangements are involved [Coase (1972), p. 73); Williamson (1992)]. Such an approach has already proved influential in the area of vertical relations, fostering a more tolerant attitude toward relations between firms and their suppliers and dealers [Williamson (1992); Joskow (1991)]. Viewing organizational arrangements in their entirety may similarly temper antitrust hostility to some horizontal relations.

\section{References}

American Society of Mechanical Engineers, Inc. v. Hydrolevel Corp., 1982, 456 U.S. 556.

Atkinson, Anthony B. and Joseph E. Stiglitz, 1980, Lectures in Public Economics (McGraw-Hill, New York).

Ayres, Ian, 1989, Colleges in Collusion, The New Republic (October 16), 19-20.

Barbezat, Debra A., 1989, The effect of collective bargaining on salaries in higher education, Industrial and Labor Relations Review 42, 443-455.

Becker, Gary, 1989, If colleges are fixing prices, it's a job for antitrust, Business Week (September 25), 30.

Board of Curators of the University of Mississippi v Horowitz, 1978, 435 U.S. 78, 98 S. Ct. 948.

Bok, Derek, 1991, What's wrong with our universities?, Harvard Journal of Law and Public Policy 14, 305-333.

Broadcast Music, Inc., v. Columbia Broadcasting System, 1979, 441 U.S. 1.

Butterfield, Fox, 1983, 23 Colleges in East adjust aid to avert bidding for Students, New York Times (April 15). 
Carlton, Dennis W., Gustavo Bamberger, and Roy Epstein, 1992, Antitrust and higher education: What are the determinants of tuition? (Mimeo, September, 1992).

Clark, Robert C., 1985, Agency costs versus fiduciary duties, in John Pratt and Richard Zeckhauser, eds., Principals and Agents: The Structure of Business. (Harvard Business School Press, Boston) $55-79,217-219$.

Coase, Ronald, 1972, Industrial organization: A proposal for research, in Victor R. Fuchs, ed., Policy Issues and Research Opportunities in Industrial Organization (National Bureau of Economic Research: New York) 59-73.

College Scholarship Service, 1986, CSS Need Analysis: Theory and Computation Procedures (College Board, New York).

Colleges and Universities, 1976, 15A Am. Jur. 2d.

Dodge, Susan, 1989, Overlap group makes aid process fairer, targets of inquiry argue, The Chronicle of Higher Education (October 11) A32-A33.

Feldstein, Martin, 1992, College scholarship rules and private saving, NBER Working Paper No. 4032, March.

Fraas, Arthur G. and Douglas F. Greer, 1977, Market structure and price collusion: An empirical analysis, Journal of Industrial Economics 26, 21-44.

Goldfarb v. Virginia State Bar, 1975, 421 U.S. 773.

Government's Trial Brief, 1992, Civil Action No. 91-CV-3274, June 22.

Guthrie-Morse, Barbara, Larry L. Leslie, and Teh-Wei Hu, 1981, Assessing the impact of faculty unions: The financial implications of collective bargaining, Journal of Higher Education 52, 237-255.

Hamilton, Robert W., 1987, The Law of Corporations. (West Publishing Co., St. Paul).

Hansmann, Henry, 1980, The role of nonprofit enterprise, Yale Law Review 89, 835-899.

Hansmann, Henry, 1986, A theory of status organizations, Journal of Law, Economics, and Organization 2, 119-130.

Hay, George A. and Daniel Kelley, 1974, An empirical survey of price fixing conspiracies, Journal of Law and Economics 17, 13-38.

Heckman, James J., 1979, Sample selection bias as a specification error, Econometrica 47, 153-161.

James, Estelle and Susan Rose-Ackerman, 1986, The Nonprofit Enterprise in Market Economies (Harwood Academic Publishers, New York).

Jaschik, Scott, 1992, Overlap group documents indicate colleges questioned the effectiveness of aid awards, The Chronicle of Higher Education (May 20), A19, A21-22.

Joskow, Paul L., 1991, The role of transaction cost economics in antitrust and public utility regulatory policies, Journal of Law, Economics, and Organization 7, 53-83.

Masten, Scott E., 1993, Transaction costs, mistakes, and performance: Assessing the importance of governance, Managerial and Decision Economics 14, 119-129.

Milgrom, Paul and John Roberts, 1992, Economics, Organization \& Management (Prentice Hall, Englewood Cliffs, NJ).

MIT's Brief in opposition to the antitrust division's motion for summary judgement, 1992, Civil Action No. 91-CV-3274.

MIT's Post-Trial Memorandum, 1992, Civil Action No. 91-CV-3274, July 24.

Mongell, Susan and Alvin E. Roth, 1991, Sorrority rush as a two-sided matching mechanism, American Economic Review 81, 441-464.

National Society of Professional Engineers v. United States, 1978, 435 U.S. 679.

NCAA v. Board of Regents of the University of Oklahoma, 1984, 486 U.S. 85, 104 S. Ct. 2948.

Oakland, William H., 1974, Public goods, perfect competition, and underproduction, Journal of Political Economy 82, 927-39.

Posner, Richard A., 1970, A statistical study of antitrust enforcement, Journal of Law and Economics 13, 365-419.

Posner, Richard A., 1975, The social costs of monopoly and regulation, Joumal of Political Economy 83, 807-827. 
Putka, Gary, 1989, Do colleges collude on financial aid?, The Wall Street Journal (May 2) B1.

Putka, Gary, 1992, Ivy League discussions on finances extended to tuition and salaries, Wall Street Journal (May 8) A1, A4.

Roth, Alvin E., 1984, The evolution of the labor market for medical interns and residents: A case study in game theory, Journal of Political Economy 92, 991-1016.

Roth, Alvin E., 1985, The college admissions problem is not equivalent to the marriage problem, Journal of Economic Theory 36, 277-288.

Roth, Alvin E. and Marilda Sotomayor, 1989, The college admissions problem revisited, Econometrica, 559-570.

Rothschild, Michael and Lawrence J. White, 1991, The university in the marketplace: Some insights and some puzzles, NBER Working Paper No. 3853.

Salop, Steven C. and Lawrence J. White, 1991, Antitrust goes to college, Journal of Economic Perspectives 5, 193-202.

Spence, $\Lambda$. Michael, 1975, Monopoly, quality, and regulation, Bell Journal of Economics 6, 417-429.

Stigler, George, 1964, A theory of oligopoly, Journal of Political Economy 72, 44-61.

Trial Testimony, 1992, Civil Action No. 91-CV-3274, June 30.

U.S. Department of Education, 1991, Digest of Education Statistics, 1990 (National Center for Education Statistics, Washington, D.C).

U.S. News and World Report, 1987, America's Best Colleges, October 26.

U.S. v. Brown University et al., 1992, 805 F.Supp. 288.

U.S. v. Brown University et al., 1993, 5 F.3d 658.

Weisbrod, Burton A., 1988, The Nonprofit Economy (Harvard Univ. Press, Cambridge).

Williamson, Oliver E., 1986, The Economic Institutions of Capitalism (Free Press, New York).

Williamson, Oliver E., 1992, Antitrust lenses and the uses of transaction cost economics reasoning, in Thomas M Jorde and David J. Teece, eds., Antitrust, Innovation, and Competitiveness (Oxford Univ. Press, New York).

Winter, Ralph A., 1993, Vertical control and price versus non-price competition, Quarterly Journal of Economics 108, 61-76. 